\title{
Characterization of a Viral EPS-Depolymerase, a Potential Tool for Control of Fire Blight
}

\author{
Won-Sik Kim and Klaus Geider
}

Max-Planck-Institut für Zellbiologie, Rosenhof, D-68526 Ladenburg, Germany. Accepted for publication 19 July 2000.

\section{ABSTRACT}

Kim, W.-S., and Geider, K. 2000. Characterization of a viral EPSdepolymerase, a potential tool for control of fire blight. Phytopathology 90:1263-1268.

A 3.3-kb fragment of genomic DNA from bacteriophage $\phi$-Ea1h encoding an amylovoran-directed depolymerase lyase was sequenced, and three open reading frames (ORFs) were detected. The first ORF could encode a lysozyme and the second a holin that may form a pore supporting cell lysis by the lysozyme. The third ORF encodes a protein of 657 amino acids and deletion mutation in this DNA fragment abolished extracellular polysaccharide (EPS)-degrading activity. A putative promoter and a ribosome binding sequence were located in front of the gene. A polymerase chain reaction product spanning the gene was inserted into multi- copy plasmids including fusions with a Histidine-tagged sequence to facilitate its purification on a nickel nitrilotriacetic acid column. Maximal activity of the purified protein was observed between $\mathrm{pH} 4$ and 5 at $52^{\circ} \mathrm{C}$. Visualized by staining with fluorescein isothiocyanate-labeled lectin from Abrus precatorious, the enzyme degraded the EPS-capsules of Erwina amylovora. In virulence assays, no symptoms were detected for a low inoculum of an E. amylovora strain when pear slices were soaked in a solution of depolymerase in contrast to control slices without addition of the enzyme. Furthermore, gfp- or lux-labeled E. amylovora cells were not propagated, when their amylovoran capsules were removed by the depolymerase. The enzyme could be a tool for biological control of fire blight.

Additional keywords: amylovoran lyase, enzymatic EPS degradation.
Extracellular polysaccharide (EPS) is a major virulence factor of Erwinia amylovora, the causative agent of fire blight $(4,9)$ associated with (i) binding of water, ions, and nutrients; (ii) keeping them in close contact with the bacteria; and (iii) protection against the recognition by plant cell defense mechanisms (21). EPSdeficient mutants are nonpathogenic $(4,5,32)$.

Some bacteriophages carry coat proteins that can degrade bacterial polysaccharides (1). The depolymerase binds to the capsular EPS (secondary receptor) and degrades the polymer until the phage reaches the cell surface, where it binds to an outer membrane receptor and injects nucleic acid to initiate the lytic cycle. The EPS-depolymerase amylovora lyase seems to be associated with small spike proteins attached to the viral base-plate $(22,33)$. Phage $\phi$-Ea1h produces clear plaques surrounded by translucent halos when grown on a lawn of E. amylovora (30). From partial digests of the viral genome, a DNA fragment expressing EPS-depolymerase was isolated by screening Escherichia coli cells forming halos with EPS degradation on a lawn of E. amylovora (15).

In this study, the 3.3-kb viral fragment was characterized by nucleotide sequencing. An open reading frame (ORF) was assigned to encode for EPS-depolymerase activity. The gene was subcloned into other vectors including Histidine-tagged (His-tag) fusions, and the encoded enzyme was studied for its biochemical properties. Application to pear slices diminished the formation of virulence symptoms and confined the decapsulated E. amylovora cells to the inoculation site, presumably by exposing them to plant defense mechanisms.

\section{MATERIALS AND METHODS}

Bacterial strains and plasmids. Strains of E. amylovora and E. coli as well as the plasmids used in this study are listed in

Corresponding author: K. Geider; E-mail address: kgeider@zellbio.mpg.de

Publication no. P-2000-0831-01R

(C) 2000 The American Phytopathological Society
Table 1. Luria-Bertani medium (3) and minimal medium (MM2A) were used for growth of bacteria. MM2A is MM2 (3) with $1 \mathrm{~g}$ of $\mathrm{K}_{2} \mathrm{HPO}_{4}$ and $1 \mathrm{~g}$ of $\mathrm{KH}_{2} \mathrm{PO}_{4}$ per liter to lower the $\mathrm{pH}$ to 6.5 .

DNA sequencing and sequence analysis. Nucleotide sequences were determined by the dideoxy-chain termination method (31) using an automatic sequencer (ALF Express; Amersham Pharmacia Biotech, Uppsala, Sweden). The DNA and deduced amino acid sequences were analyzed with the sequence analysis program Clone Manager version 5 (Scientific and Educational Software, State Line, PA). Database searches were performed on the Internet with the programs BLASTP + BEAUTY (36) and emotif-search/identify (24). The nucleotide sequence data were deposited in the European Molecular Biology Laboratory (EMBL) nucleotide sequence database (accession number AJ278614).

Cloning of the dpo gene by polymerase chain reaction and construction of a His-dpo fusion protein. Polymerase chain reaction (PCR) assays were carried out in a volume of $50 \mu \mathrm{l}$ with $10 \mathrm{ng}$ of template DNA and 2.5 units of $p f u$ DNA polymerase (Stratagene, La Jolla, CA) as described previously (18). The intact dpo gene was amplified by PCR with the forward primer DPO5 (5'-GCGCGGTCGACCACCAAGGGAGGCATAA; the introduced SalI site is underlined) and the complementary primer DPO3c (5'-GCGCGCTCTAGATATTCGTTACGTGTTAG; the introduced $\mathrm{Xba \textrm {I }}$ site is underlined) derived from the nucleotide sequence of the insert in plasmid pJH94. The PCR fragment was purified with a gel extraction kit (Qiaex II; Qiagen, Hilden, Germany), digested with SalI and XbaI, and ligated into the corresponding sites of pBlueKS ${ }^{+}$. Plasmid pBlue-dpo was digested with $K p n \mathrm{I}$ and $\mathrm{Xba \textrm {I }}$ and a 2-kb DNA fragment extracted from the gel, ligated into pUC19 against the lac promoter, and named pUC19dpo. For a His-dpo fusion, the 2-kb DNA fragment was digested with SacI and HindIII and ligated into pQE31, and the resulting plasmid pQE31-dpo was transformed into E. coli GI698.

Purification of the His-dpo fusion protein. E. coli GI698 (pQE31-dpo) was cultured at $37^{\circ} \mathrm{C}$ in 1 liter of StI medium (E. Merck AG, Darmstadt, Germany) containing ampicillin $(100 \mu \mathrm{g} / \mathrm{ml})$ 
to a cell density $\left(\mathrm{A}_{600}\right)$ of 0.7 . Isopropyl- $\beta$-D-thiogalactopyranoside (IPTG) was added to $1 \mathrm{mM}$, and the culture was incubated for $4 \mathrm{~h}$ at $18^{\circ} \mathrm{C}$. The cells were harvested by centrifugation at $4,000 \times g$ for $20 \mathrm{~min}$, suspended in $12 \mathrm{ml}$ of buffer A $(50 \mathrm{mM}$ $\mathrm{NaH}_{2} \mathrm{PO}_{4}, 300 \mathrm{mM} \mathrm{NaCl}$, and $10 \mathrm{mM}$ imidazole [pH 8.0]), and opened by sonication. For selective purification of the His-tag protein which binds to nickel ions, the cell debris was removed by centrifugation at $10,000 \times g$ for $20 \mathrm{~min}$ and $4 \mathrm{ml}$ of supernatant was gently mixed with $1 \mathrm{ml}$ of a $50 \%$ nickel nitrilotriacetic acid slurry (Qiagen) followed by shaking at $4^{\circ} \mathrm{C}$ for $60 \mathrm{~min}$ and loaded on a column. The column was washed with 8 column volumes of buffer A with $20 \mathrm{mM}$ imidazole and eluted with 2 column volumes of buffer A with $250 \mathrm{mM}$ imidazole. The protein concentration was measured according to the method of Lowry et al. (23). The eluted enzyme was stored with $20 \%$ glycerol at $-80^{\circ} \mathrm{C}$.

Sodium dodecyl sulfate-polyacrylamide gel electrophoresis and western analysis. Sodium dodecyl sulfate-polyacrylamide gel electrophoresis (SDS-PAGE) of protein was performed in $10 \%$ polyacrylamide gels (11). Proteins were transferred to nylon plus membranes (Qiagen) with a Mini Trans-Blot apparatus as recommended by the manufacturer (Bio-Rad Laboratories, Hercules, $\mathrm{CA}$ ), and blots were treated by standard technique (16). The first

TABLE 1. Bacterial strains and plasmids used in this study

\begin{tabular}{|c|c|c|}
\hline Strains or plasmid & Phenotype/relevant characteristics & Source \\
\hline \multicolumn{3}{|l|}{ Bacterial strains } \\
\hline \multicolumn{3}{|l|}{ Erwina amylovora } \\
\hline $\mathrm{Ea} 1 / 79$ & From Cotoneaster sp.; Germany 1979 & 12 \\
\hline Escherichia coli & & \\
\hline DH5 $\alpha$ & $\begin{array}{l}\text { end } A 1, \text { hs } d \mathrm{R} 17\left(\mathrm{r}_{\mathrm{k}}{ }^{-} \mathrm{m}_{\mathrm{k}}{ }^{+}\right) \text {, sup } \mathrm{E} 44, \text { thi }, \\
\text { recA } 1, \text { gyrA } 96, \text { relA } 1, \text { LlacZM15 }\end{array}$ & BRL \\
\hline GI698 & $\lambda^{-}$, lac $^{\mathrm{q}}$, lac $\mathrm{PL} 8$, amp $\mathrm{C}:: \mathrm{P}_{\mathrm{trp}} c \mathrm{I}$ & Invitrogen \\
\hline \multicolumn{3}{|c|}{ 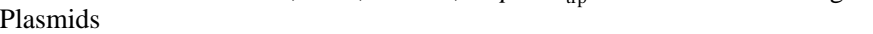 } \\
\hline pUC19 & ColE1 ori, lac $\mathrm{Z}^{\prime}, \mathrm{Ap}^{\mathrm{r}}$ & 37 \\
\hline pBlueKS ${ }^{+}$ & pBluescriptKS $S^{+}$, colE1 ori, lac $Z^{\prime}, \mathrm{Ap}^{\mathrm{r}}$ & Stratagene \\
\hline pQE31 & 6xHis-tag, colE1 ori, $\mathrm{Ap}^{\mathrm{r}}$ & Qiagen \\
\hline pJH94 & $\begin{array}{l}\text { 3.3-kb insertion after partial Sau3A } \\
\text { digest of DNA from phage } \phi \text {-Ea1h in } \\
\text { pUC8, Ap }{ }^{\mathrm{r}}\end{array}$ & 15 \\
\hline pJH94-DE & $\begin{array}{l}\text { Deletion of 0.9-kb EcoRI fragment at 3' } \\
\text { end of dpo in pJH94, } \mathrm{Ap}^{\mathrm{r}}\end{array}$ & This study \\
\hline pBlue-dpo & $\begin{array}{l}\text { 2.0-kb PCR SalI-XbaI fragment of } d p o \\
\text { from pJH94 in pBlueKS } \\
\text { of } l a c \text { promoter, } \mathrm{Ap}^{\mathrm{r}}\end{array}$ & This study \\
\hline pUC19-dpo & $\begin{array}{l}\text { 2.0-kb KpnI-XbaI fragment from pBlue- } \\
\text { dpo, in pUC19, against the lac } \\
\text { promoter, } \text { Ap }^{\mathrm{r}}\end{array}$ & This study \\
\hline pQE31-dpo & $\begin{array}{l}\text { 2.0-kb SacI-HindIII fragment from } \\
\text { pUC19-dpo inserted in pQE-31, } \mathrm{Ap}^{\mathrm{r}}\end{array}$ & This study \\
\hline
\end{tabular}

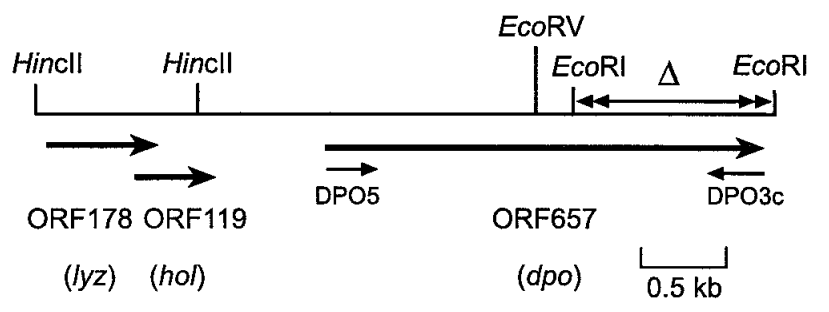

Fig. 1. Genetic map of the 3.3-kb fragment inserted in pJH94. The primers DPO5, and DPO3c were used for cloning of the dpo gene. lyz, lysozyme; hol, holin; dpo, depolymerase. $\Delta$ indicates the EcoRI fragment deleted in pHJ94-DE. antibody was the Arg-Gly-Ser His antibody (Qiagen), and the secondary antibody was goat antimouse immunoglobulin G coupled to alkaline phosphatase (Sigma Chemical Co., St. Louis).

EPS degradation assays. The concentration of undegraded EPS was measured with the cetylpyridinium chloride (CPC) method according to Bellemann et al. (3). Enzyme activity was determined in 100- $\mu$ l assays containing EPS depolymerase (diluted in $50 \mathrm{mM} \mathrm{NaCl}, 0.1 \mathrm{mg} / \mathrm{ml}$ bovine serum albumin, and $10 \mathrm{mM}$ Tris- $\mathrm{Cl}\left[\mathrm{pH} \mathrm{8.0]}\right.$ ) and $100 \mu \mathrm{g}$ of EPS at $37^{\circ} \mathrm{C}$ for $60 \mathrm{~min}$ in $50 \mathrm{mM}$ sodium acetate buffer $(\mathrm{pH} 4.7)$. One unit of EPS depolymerase was defined as the activity which degrades $1.5 \mu \mathrm{g}$ of EPS per $\mathrm{h}$ at $37^{\circ} \mathrm{C}$. For assays at other $\mathrm{pH}$ ranges, the enzyme was incubated at $28^{\circ} \mathrm{C}$ for $60 \mathrm{~min}$ in $50 \mathrm{mM}$ acetate buffer $(\mathrm{pH} \mathrm{3.0,}$ 4.0, and 5.0), potassium phosphate buffer ( $\mathrm{pH} 6.0$ and 7.0), or Tris- $\mathrm{Cl}$ buffer $(\mathrm{pH} 8.0$ and 9.0) or at various temperatures in the standard buffer $50 \mathrm{mM}$ acetate ( $\mathrm{pH} 4.7)$.

Plant assays and degradation of capsules. Immature pears were sliced (5-mm thick), and cylinders $(\varnothing 8 \mathrm{~mm})$ were cut out and soaked for $1 \mathrm{~h}$ in an Eppendorf tube with a cleared lysate from sonicated E. coli cells GI698(pQE31-dpo), which was diluted in water to a protein concentration of $30 \mu \mathrm{g} / \mathrm{ml}$. They were placed in an open petri dish and dried for $30 \mathrm{~min}$ in a laminar air flow cabinet. An overnight culture was diluted in water to a density of $50,000,5,000,500$, and 50 cells per $10 \mu \mathrm{l}$ and applied to the surface of the pear slices that were incubated in an airtight plastic box at $26^{\circ} \mathrm{C}$. Symptoms were rated 1 week after inoculation on a scale of 0 (no ooze formation and little or no necrosis) to 4 (ooze as large drops or a fluidal layer on the surface).

For capsule degradation, Ea1/79 was grown for 2 days on MM2A agar (3) and cells were transferred on a glass slide; a 5- $\mu$ l solution with purified His-tag depolymerase was added, gently mixed, and cells were incubated for $15 \mathrm{~min}$. Then, $5 \mu \mathrm{l}$ fluorescein isothiocyanate-labeled lectin from Abrus precatorius (Sigma Chemical) was added, which specifically binds to the galactose residue of the amylovoran side chain. The slide was mounted and the bacteria visualized in a fluorescence microscope in brightfield and UV with an oil immersion lens at 63-fold magnification (Axiovert 405; Zeiss, Oberkochen, Germany) and the filter combination BP450-490/FT510/LP520 (excitation filter/dichroic/emission filter) as described previously (3).

\section{RESULTS}

Sequence analysis of pJH94 and cloning of the EPS depolymerase lyase gene. Both strands of the DNA insert of plasmid pJH94 (15) were sequenced. Three ORFs (Fig. 1) were oriented against the lac promoter and were preceded by a putative ribosomal binding site (RBS) typical for many prokaryotic genes (AGGAGG) (Table 2). The largest ORF (1,974 bp) was found in biochemical assays to encode an EPS-degrading enzyme. The dpo gene showed an RBS at nucleotides -11 to -5 from the assumed start codon and was terminated by the stop codon TAA. The deduced polypeptide is a protein of 657 amino acid residues corresponding to a molecular mass of $71 \mathrm{kDa}$. In the sequence homology search with BLASTP + BEAUTY, AmsF, involved in amylovoran biosynthesis of E. amylovora, had the highest homology (40\%) in the data library for the deduced protein.

Two additional ORFs on the cloned fragment had a size of 540 and 360 bp encoding 179 and 119 amino acids, respectively. Searches in data libraries revealed significant homology to viral lysozymes for ORF179 and holins for ORF119.

TABLE 2. Properties of open reading frames (ORFs) in pJH94

\begin{tabular}{lcccccc}
\hline ORF/putative gene & Ribosomal binding site & No. amino acids & Protein (kDa) & PI value $(\mathrm{pH})$ & Putative start/stop codon & Possible protein function \\
\hline ORF178/lyz & AGGAGGCT & 179 & 19.2 & 8.81 & ATG/TAG & Lysozyme (Lyz) \\
ORF119/hol & AGGACAT & 119 & 13.1 & 7.71 & ATG/TGA & Holin (Hol) \\
ORF657/dpo & AGGGAGG & 657 & 71.0 & 6.07 & ATG/TAA & Depolymerase (Dpo) \\
\hline
\end{tabular}


Functional analysis of putative Dpo. In order to localize the depolymerase gene, pJH94-DE was constructed by deleting the $0.9-\mathrm{kb}$ EcoRI fragment at the 3' end of the putative dpo gene in pJH94. The deletion resulted in a loss of depolymerase expression from carrier cells, which localized the encoding gene to the end of the insert in pJH94. Amplification of the dpo gene in pJH94 by PCR with primers DPO5 and DPO3c gave a DNA fragment of $2.0 \mathrm{~kb}$, which was cloned into pBlueKS ${ }^{+}$and cleaved with $S a l \mathrm{I}$ and $\mathrm{XbaI}$, placing the ORF in the direction of the lac promoter. Supernatants of sonicated cells of the E. coli strain DH5 $\alpha$ (pBlue-dpo) degraded EPS when assayed with the CPC method, showing expression of dpo. The 2-kb fragment was also inserted in pUC19-dpo against the lac promoter, which abolished dpo expression. E. amylovora Ea1/79 cells with pJH94 or pBlue-dpo were not mucoid on MM2A agar plates in contrast to wild-type cells. Also in liquid medium, the EPS produced by Ea1/79(pJH94) was degraded more quickly than that of Ea1/79(pBlue-dpo). The phage promoter in pJH94 was apparently more efficient for expression of enzyme activity than the lac promoter in pBlue-dpo. These results confirm expression of depolymerase from pJH94 and pBlue-dpo. On the other hand, cell growth was not retarded by $d p o$ expression, and the enzyme might not be toxic to E. amylovora.

Expression and purification of His-tag EPS depolymerase. Plasmid pQE31-dpo was constructed with a His-tag sequence at its $\mathrm{N}$ terminus fused to the structural $d p o$ gene. The His-tag $d p o$ gene encodes a polypeptide of 688 amino acids with a molecular weight of $74 \mathrm{kDa}$. Plasmid pQE31-dpo was introduced into E. coli GI698, and the His-Dpo protein was expressed at $18^{\circ} \mathrm{C}$ after addition of $1 \mathrm{mM}$ IPTG. A protein with the expected size of His-Dpo accumulated in GI698(pQE31-dpo) (Fig. 2, lane 2) and no dominant protein band at this position was observed in GI698(pQE31) (Fig. 2, lane 1). The His-Dpo was purified by nickel affinity chromatography, and gave a single band on a SDS-polyacrylamide gel at $74 \mathrm{kDa}$ (Fig. 2, lane 5). A western blot analysis detected a protein at $74 \mathrm{kDa}$ that reacted with antibodies raised against the His-tag (Fig. 2, lane W).

Analysis of enzyme activity. Figure $3 \mathrm{~A}$ shows the dependence of Dpo activity on the $\mathrm{pH}$ of the reaction mixture. Optimal activity was found between $\mathrm{pH} 4.0$ and 5.0, whereas the activity of the enzyme decreased significantly at $\mathrm{pH} 3$ and above 7 . The enzyme activity increased with the temperature up to $52^{\circ} \mathrm{C}$, indicating a relatively heat-stable protein (Fig. 3B). No $\mathrm{Mg}^{2+}$ ions were required for the EPS-degrading activity, which was optimal at a low to intermediate salt concentration. At $300 \mathrm{mM} \mathrm{NaCl}$, the enzyme activity was reduced by at least half (data not shown).

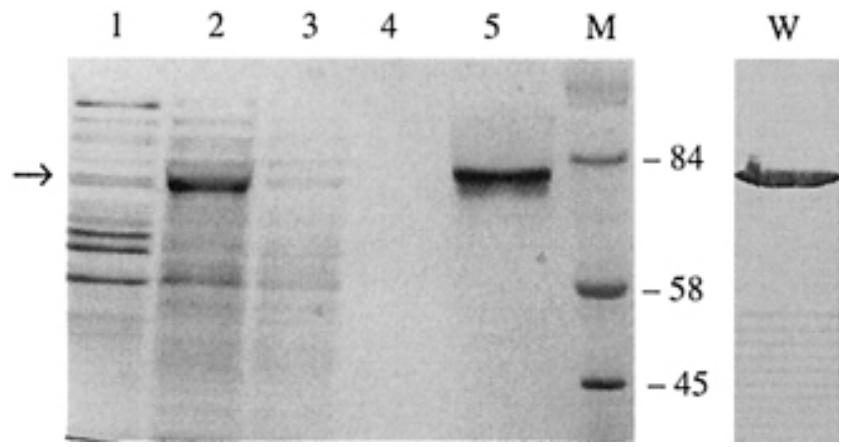

Fig. 2. Purification of Histidine-tagged (His-tag) extracellular polysaccharide (EPS) depolymerase with nickel nitrilotriacetic acid column chromatography under native conditions. Aliquots $(30 \mu \mathrm{l})$ from column fractions $(2 \mathrm{ml})$ and cell lysates were separated on a $10 \%$ sodium dodecyl sulfate-polyacrylamide gel and stained with Coomassie blue. The arrow on the left points to the position of $74 \mathrm{kDa}$ expected for the His-tag depolymerase. Lane 1, lysate of GI698(pQE31); lane 2, lysate of GI698(pQE31-Dpo) induced with isopropyl $\beta$-D-thiogalactopyranoside at $18^{\circ} \mathrm{C}$; lane 3 , flow-through of column; lane 4 , wash; lane 5, eluted enzyme; M, molecular weight markers; W, western blot analysis with Arg-Gly-Ser His-antibody.
Capsule degradation and virulence assays on pear slices treated with His-Dpo. Uncapsulated E. amylovora cells did not propagate in plant tissue (4), presumably due to exposure to plant defense reactions. Purified EPS-depolymerase degraded amylovoran capsules under standard conditions (described previously) depending on the enzyme concentration (Fig. 4). For $0.17 \mathrm{ng}$ of depolymerase, 30 to $40 \%$ of the cells had no or very thin capsules; for $0.5 \mathrm{ng}$ of enzyme, $80 \%$ of the cells were without capsules; for $1.7 \mathrm{ng}$, most capsules were removed from the cells; and in the control without depolymerase, more than $80 \%$ of the cells were

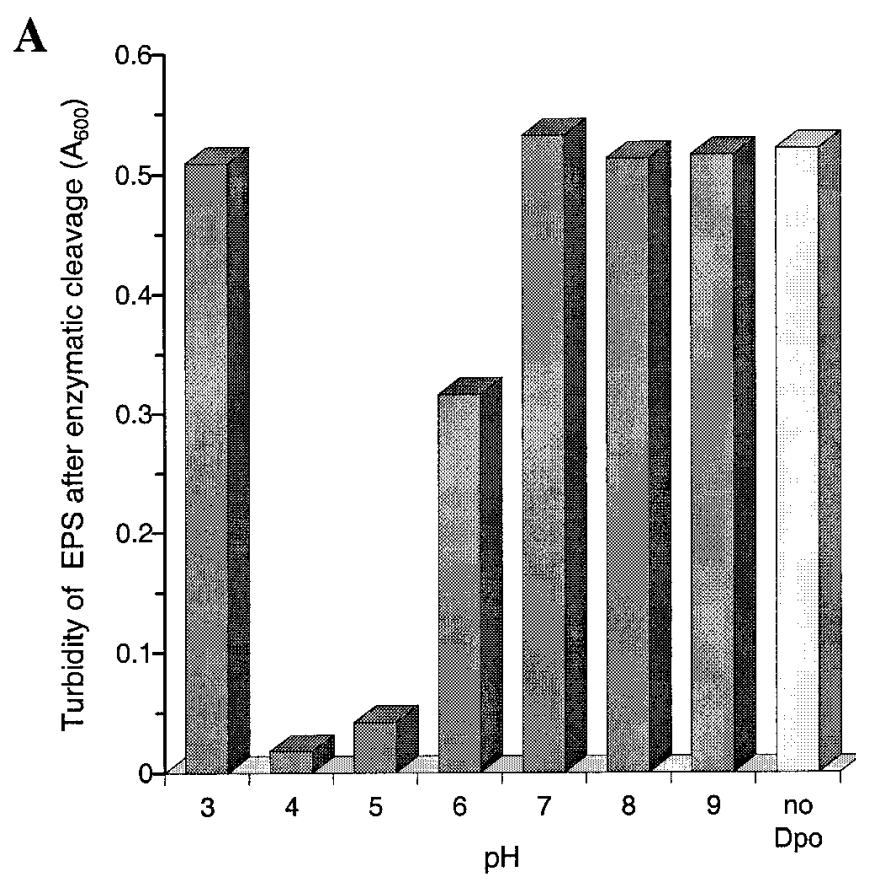

B

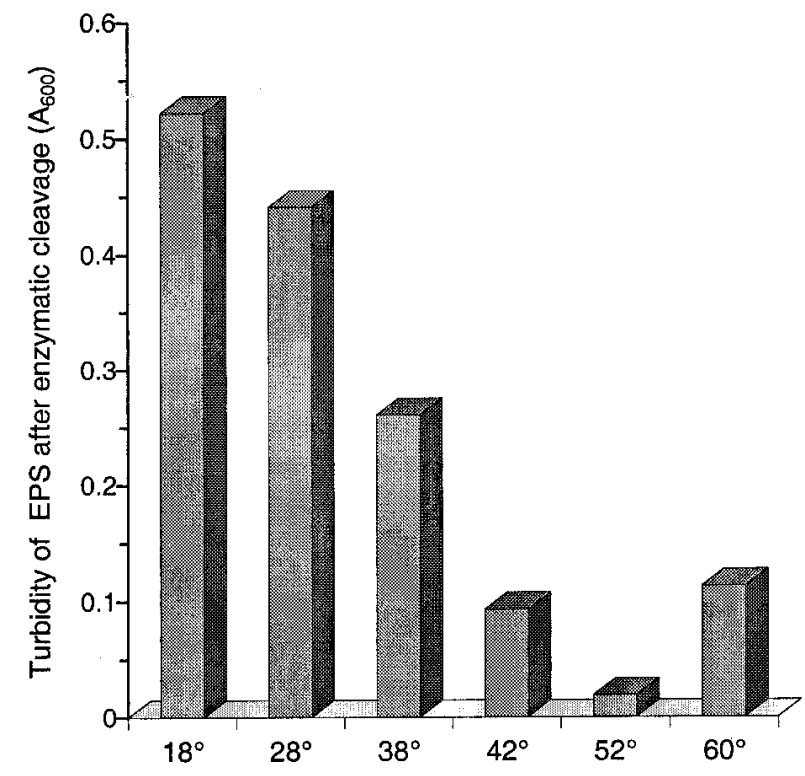

Fig. 3. A, Extracellular polysaccharide (EPS) degradation by purified depolymerase at various $\mathrm{pH}$ values. The enzyme activity (as loss of turbidity after addition of cetylpyridinium chloride to the amylovoran solution) was measured after $60 \mathrm{~min}$ incubation at $52^{\circ} \mathrm{C}$ with $50 \mathrm{mM}$ sodium acetate (pH 3.0, 4.0, and 5.0), $50 \mathrm{mM}$ potassium phosphate buffer $(\mathrm{pH} 6.0$ and 7.0) and Tris-Cl buffer (pH 8.0 and 9.0). Light bar indicates control without EPS degradation. B, Depolymerase activity at various temperatures. Each reaction was performed in the standard reaction mixture at $\mathrm{pH} 4.7$. 
capsulated. The data showed an efficient degradation of the amylovoran capsules after addition of purified His-tagged depolymerase.

To assay colonization of uncapsulated E. amylovora cells, pear slices were soaked in a solution of partially purified depolymerase, inoculated with various amounts of E. amylovora Ea1/79 on the surface, and monitored for necrotic symptoms and production of ooze. The control slices that were soaked in water and inoculated with the same amount of cells were covered with ooze. However, treatment with depolymerase inhibited the symptoms development especially at low inoculum densities (Fig. 5). In addition, when evaluated under UV light or on X-ray films, Ea1/79 cells that had been labeled with reporter genes such as $g f p$ or lux $(8,13)$ were confined to the inoculation site on pear slices soaked with depolymerase but not on control slices treated with water.

\section{DISCUSSION}

The capsular polysaccharide amylovoran of E. amylovora consists of highly polymerized repeating units (17) and is loosely

\section{A}
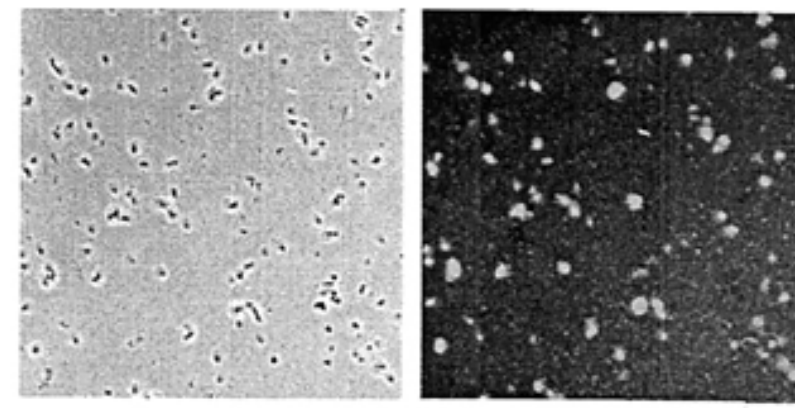

B

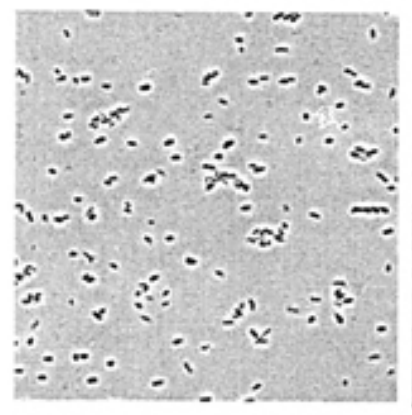

C

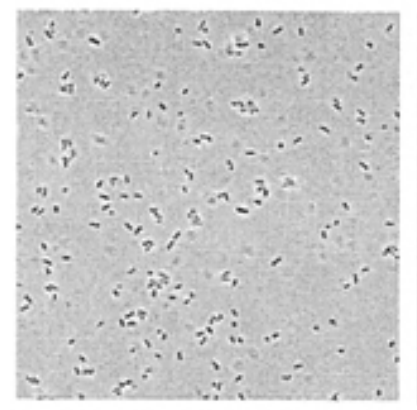

D
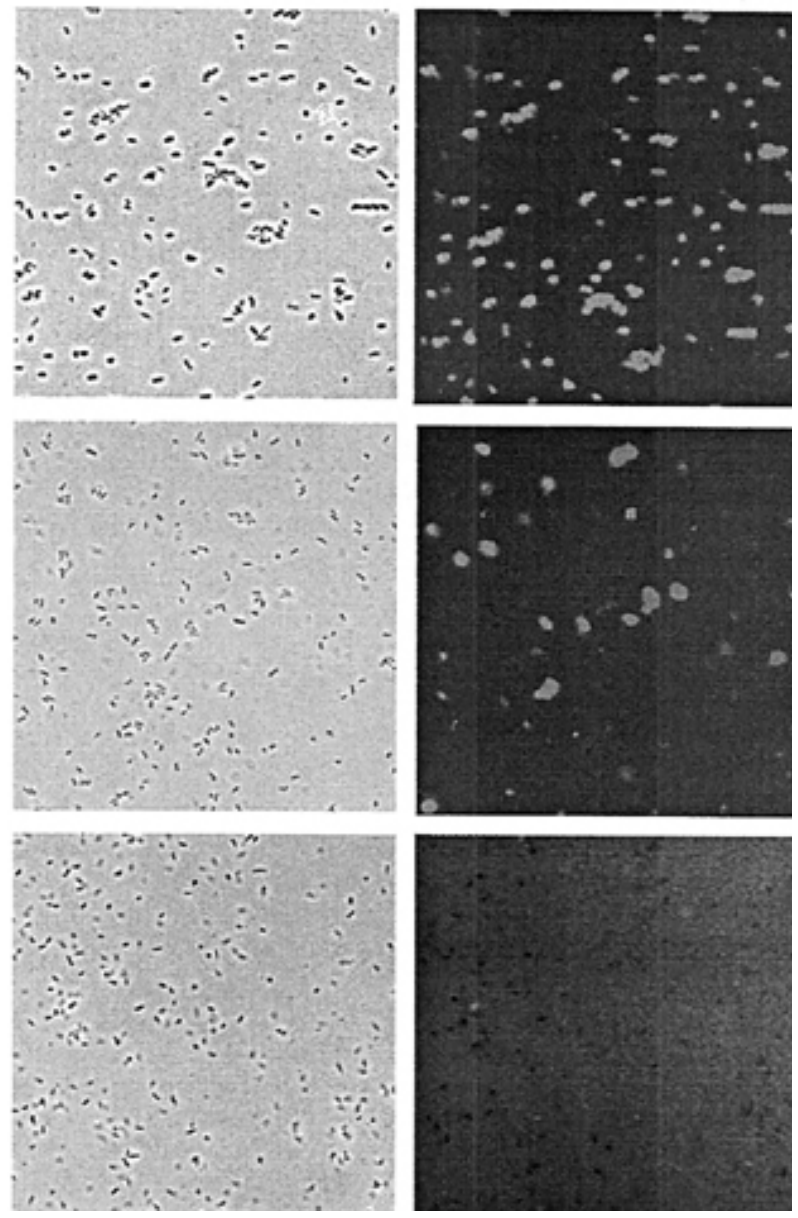

Fig. 4. Degradation of amylovoran capsules by exposure to extracellular polysaccharide-depolymerase. The amounts of depolymerase (diluted in water) were: A, Water control, B, $0.17 \mathrm{ng}, \mathbf{C}, 0.5 \mathrm{ng}$, and $\mathbf{D}, 1.7 \mathrm{ng}$. Cells were visualized in bright field (left column) and UV light (right column). attached to the cells (28). Its sugar composition and linkage was determined and comprised three galactose molecules in the backbone and a glucuronic acid residue, another galactose, and a terminal pyruvate in the side chain (25). The repeating units of stewartan from Pantoea stewartii are similar, but a galactose residue in the backbone is replaced by glucose and the side chain is terminated by glucose (26). Both EPS species are cleaved by depolymerase from phage $\phi$-Ealh (6). The cleavage site for the enzyme is located between two galactose residues. The cleavage in low molecular weight fragments was determined by a turbidity assay (3).

Many plant-pathogenic bacteria cause a hypersensitive response on nonhost plants (20). For E. amylovora, a complex chromosomal region is required for a positive reaction (19). Small proteins encoded by $h r p N$ and $h r p W(2,35)$ are presumably delivered to the cell surface and mediate cellular recognition by plant defense mechanisms. We assume that EPS capsules modulate this process to decrease the interaction between the pathogen and the plant cells. Mutations of E. amylovora that abolish amylovoran synthesis resulted in strains deficient for host colonization (4).

Degradation of amylovoran capsules gives the E. amylovora phage $\phi$-Ea1h access to the host surface to inject DNA for the start of its lytic cycle. The bacteriophage degrades amylovoran and stewartan into repeating units that have been characterized by methylation analysis and nuclear magnetic resonance $(6,25,26)$. The gene for the EPS degrading enzyme was located on a 3.3-kb DNA fragment obtained from a partial digest of DNA from bacteriophage $\phi$-Ea1h (15). E. coli colonies with this DNA fragment formed halos on a lawn of EPS-producing E. amylovora cells. In the present study, we determined the nucleotide sequence of the responsible gene and detected two additional ORFs. The first one had a striking homology with lysozyme genes and the other ORF with holins, which form channels in the cell membrane for transport of lysozyme into the periplasm to lyse the host cells of the phage (7).

Due to its viral promoter, the $d p o$ gene is highly expressed in $E$. amylovora, but could be separated from its promoter and con-

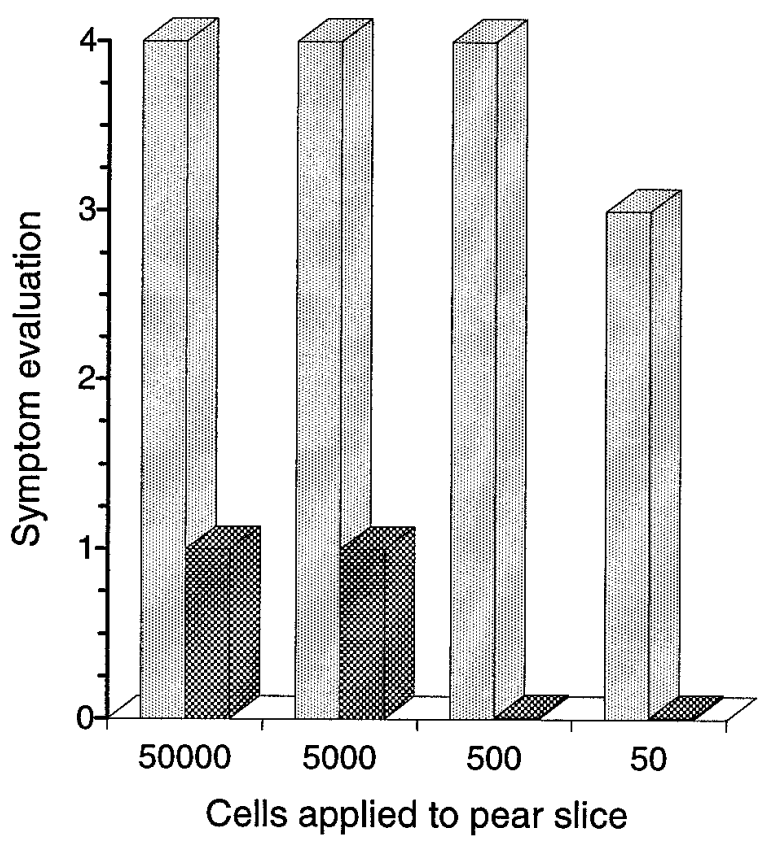

Fig. 5. Virulence assay for pear slices soaked with depolymerase and inoculated with Erwinia amylovora. Dark bars: Rating of symptoms (0 to 4, no ooze formation and necrosis to heavy symptoms) for pear slices pretreated with crude depolymerase and inoculated with various amounts of $E$. amylovora Ea1/79. Light bars: Control slices treated with water and inoculated with E. amylovora. Incubation was for 7 days at $28^{\circ} \mathrm{C}$. The experiments were repeated three times with $\approx 5$ pear slices per assay. 
trolled by the lac promoter. Thus, it should also be possible to express the gene via a plant-derived promoter.

The fusion of $d p o$ to a His-tag facilitated purification of the enzyme, because the nontagged protein did not bind to ion exchange columns (data not shown). In vivo it might be associated with cellular polysaccharides, because enzyme activity was retained on heparin columns. As noticed before (15), its optimal activity occurred at a low $\mathrm{pH}$, which is suitable in an acidic environment of damaged plant cells where the phage might attack E. amylovora. The enzyme does not require $\mathrm{Mg}^{2+}$ ions and is tolerant to salt. Its fitness at high temperatures might indicate degradation of EPS capsules by the phage even under conditions that prevent the growth of E. amylovora.

When an E. amylovora strain with plasmid pJH94 was inoculated into pear slices, the bacteria caused local necrosis, but in most cases no ooze formation was observed (15). This could be due to degradation of amylovoran by released depolymerase or to inactivation of uncapsulated bacteria by plant defense reactions. Uncapsulated $E$. amylovora cells did not propagate after inoculation into pear slices (4). This result was confirmed here by the $g f p$ - and lux-labeled pathogen on pear slices treated with EPSdepolymerase. The enzymatic removal of cellular capsules could also expose the pathogen to recognition by plant defense mechanisms. This property has been proposed for control of fire blight, including the possible application of enzyme preparations (34). Transgenic plants with $d p o$ expression might show reduced colonization by E. amylovora, because damaged plant cells would release the enzyme, which then would degrade the bacterial capsules and expose E. amylovora to plant defense reactions. It might thus be possible to use the depolymerase in a similar way to other genes used for control of fire blight, such as attacin and cecropine in transgenic apple (27) or pear (29). Lysozyme also has a potential for plant protection against bacterial pathogens and was used to reduce soft rot on potatoes (10) and even to control fire blight (14). Properties of the lysozyme from an E. amylovora phage might be superior to other lysozymes assuming a preference for lysis of E. amylovora. Both of the EPS-depolymerase and the lysozyme might therefore be suitable tools to decrease or even abolish colonization of fire blight host plants by E. amylovora.

\section{ACKNOWLEDGMENTS}

We thank S. Jock for support in experiments.

\section{LITERATURE CITED}

1. Adams, M. H., and Park, B. H. 1956. An enzyme produced by a phagehost cell system. II. The properties of the polysaccharide depolymerase. Virology 2:719-736.

2. Barny, M.-A. 1995. Erwinia amylovora hrpN mutants, blocked in harpin synthesis, express a reduced virulence on host plants, and elicit variable hypersensitive reactions on tobacco. Eur. J. Plant Pathol. 101:333-340.

3. Bellemann, P., Bereswill, S., Berger, S., and Geider, K. 1994. Visualization of capsule formation by Erwinia amylovora and their biochemical characterization. Int. J. Biol. Macromol. 16:290-296.

4. Bellemann, P., and Geider, K. 1992. Localization of transposon insertions in pathogenicity mutants of Erwinia amylovora and their biochemical characterization. J. Gen. Microbiol. 138:931-940.

5. Bernhard, F., Coplin, D. L., and Geider, K. 1993. A gene cluster involved in amylovoran synthesis of Erwinia amylovora: Characterization and its relationship to cps genes in Erwinia stewartii. Mol. Gen. Genet. 239: 158-168.

6. Bernhard, F., Schullerus, D., Bellemann, P., Nimtz, M., Coplin, D. L., and Geider, K. 1996. Genetic transfer of amylovoran and stewartan synthesis between Erwinia amylovora and Erwinia stewartii. Microbiology 142:1087-1096.

7. Bläsi, U., and Young, R. 1996. Two beginnings for a single purpose: The dual-start holins in the regulation of phage lysis. Mol. Microbiol. 21: 675-682.

8. Bogs, J., Bruchmüller, I., Erbar, C., and Geider, K. 1998. Colonization of host plants by the fire blight pathogen Erwinia amylovora marked with gene for bioluminescence and fluorescence. Phytopathology 88:416-421.
9. Bugert, P., and Geider, K. 1995. Molecular analysis of the ams operon required for exopolysaccharide synthesis of Erwinia amylovora. Mol. Microbiol. 15:917-933.

10. Düring, K., Porsch, P., Fladung, M., and Lörz, H. 1993. Transgenic potato plants resistant to the phytopathogenic bacterium Erwinia carotovora. Plant J. 3:587-598.

11. Egberts, E., Hackett, P. R., and Traub, P. 1976. Protein synthesis in postnuclear supernatants from mengovirus-infected Ehrlich ascites tumor cells. Hoppe-Seyler's Z. Physiol. Chem. 357:1179-1192.

12. Falkenstein, H., Bellemann, P., Walter, S., Zeller, W., and Geider, K. 1988. Identification of Erwinia amylovora, the fireblight pathogen, by colony hybridization with DNA from plasmid pEA29. Appl. Environ. Microbiol. 54:2798-2802.

13. Falkenstein, H., Zeller, W., and Geider, K. 1989. The 29-kb plasmid, common in strains of Erwinia amylovora, modulates development of fireblight symptoms. J. Gen. Microbiol. 135:2643-2650.

14. Hanke, V., Norelli, J. L., Aldwinckle, H. S., and Düring, K. 1999. Transformation of apple cultivars with T4-lysozyme-gene to increase fire blight resistance. Acta Hortic. 489:253-256.

15. Hartung, J. S., Fulbright, D. W., and Klos, E. J. 1988. Cloning of a bacteriophage polysaccharide depolymerase gene and its expression in Erwinia amylovora. Mol. Plant-Microbe Interact. 1:87-93.

16. Jonsson, C. B., Donzella, G. A., and Roth, M. J. 1993. Characterization of the forward reverse integration reactions of the moloney murine leukemia virus intergrase protein purified from Escherichia coli. J. Biol. Chem. 268:1462-1469.

17. Jumel, K., Geider, K., and Harding, S. E. 1997. The solution molecular weight and shape of the bacterial exopolysaccharides amylovoran and stewartan. Int. J. Biol. Macromol. 29:251-258.

18. Kim, W.-S., Gardan, L., Rhim, S.-L., and Geider, K. 1999. Erwinia pyrifoliae sp. nov., a novel pathogen that affects Asian pear trees (Pyrus pyrifolia Nakai). Int. J. Syst. Bacteriol. 49:899-906.

19. Kim, J. F., Wei, Z.-M., and Beer, S. V. 1997. The hrpA and $h r p C$ operons of Erwinia amylovora encode components of a type III pathway that secretes harpin. J. Bacteriol. 179:1690-1697.

20. Klement, Z., Farkas, G. L., and Lovrekovich, L. 1964. Hypersensitive reaction induced by phytopathogenic bacteria in the tobacco leaf. Phytopathology 54:474-477.

21. Leigh, J. A., and Coplin, D. L. 1992. Exopolysaccharides in plant-bacterial interaction. Annu. Rev. Microbiol. 46:307-346.

22. Lindberg, A. A. 1977. Bacterial surface carbohydrates and bacteriophage adsorption. Pages 289-356 in: Surface Carbohydrates of the Prokaryotic Cell. W. Sutherland, ed. Academic Press, London.

23. Lowry, O. H., Rosebroug, N. J., Farr, A. L., and Randall, R. J. 1951. Protein measurement with the Folin phenol reagent. J. Biol. Chem. 193:265-275.

24. Nevill-Manning, G. C., Wu, T., and Brutlag, D. L. 1998. Highly specific protein sequence motifs for genome analysis. Proc. Natl. Acad. Sci. USA 95:5865-5871.

25. Nimtz, M., Mort, A., Domke, T., Wray, V., Zhang, Y., Qiu, F., Coplin, D., and Geider, K. 1996. Structure of amylovoran, the capsular exopolysaccharide from the fireblight pathogen Erwinia amylovora. Carbohydr. Res. 287:59-76.

26. Nimtz, M., Mort, A., Wray, V., Domke, T., Zhang, Y., Coplin, D. L., and Geider, K. 1996. Structure of stewartan, the capsular exopolysaccharide from the corn pathogen Erwinia stewartii. Carbohydr. Res. 288:189-201.

27. Norelli, J. L., Mills, J. Z., Momol, M. T., and Aldwinckle, H. 1998. Effect of cecropin-like transgenes on fire blight resistance of apple. Acta Hortic. 489:273-278.

28. Politis, D. J., and Goodman, R. N. 1980. Fine structure of extracellular polysaccharide of Erwinia amylovora. Appl. Environ. Microbiol. 40:596-607.

29. Reynoird, J. P., Mourgues, F., Norelli, J., Aldwinckle, H. S., Brisset, M. N., and Chevreau, E. 1999. First evidence for improved resistance to fire blight in transgenic pear expressing the attacin $E$ gene from Hyalophora cecropia. Plant Sci. 149:23-31.

30. Ritchie, D. F., and Klos, E. J. 1977. Isolation of Erwinia amylovora bacteriophage from aerial parts of apple trees. Phytopathology 67: 101-104.

31. Sanger, F., Nicklen, S., and Coulson, A. R. 1977. DNA sequencing with chain-terminating inhibitors. Proc. Natl. Acad. Sci. USA 74:5463-5467.

32. Steinberger, E. M., and Beer, S. V. 1988. Creation and complementation of pathogenicity mutants of Erwinia amylovora. Mol. Plant-Microbe Interact. 1:135-144.

33. Stirm, S., and Freund-Mölbert, E. 1971. Escherichia coli capsule bacteriophages. II. Morphology. J. Virol. 2:1107-1114.

34. Vandenbergh, P. A., and Cole, R. L. 1986. Cloning and expression in Escherichia coli of the polysaccharide depolymerase associated with bacteriophage-infected Erwinia amylovora. Appl. Environ. Microbiol. 51:862-864. 
35. Wei, Z. M., Laby, R. J., Zumoff, C. H., Bauer, D. W., He, S. Y., Collmer, A., and Beer, S. V. 1992. Harpin, elicitor of the hypersensitive response produced by the plant pathogen Erwinia amylovora. Science 257:85-88.

36. Worley, K. C., Wiese, B. A., and Smith, R. F. 1995. BEAUTY: An enhanced BLAST-based search tool that integrates multiple biological in- formation resources into sequence similarity search results. Genome Res. 5:173-184.

37. Yanisch-Perron, C., Vieira, J., and Messing, J. 1985. Improved M13 phage cloning vectors and host strains: Nucleotide sequences of the M13mp18 and pUC19 vectors. Gene 33:103-119. 